\title{
A qualidade do gasto público e a avaliação das políticas sociais: o orçamento do Ministério do Trabalho no período $2000-2006^{*}$
}

\section{Luis Henrique Paiva}

\section{Introdução}

A qualidade do gasto público é tema de crescente importância política, administrativa e acadêmica. As avaliações mais gerais do gasto público, entretanto, pouco podem fazer, além de apontarem grandes dilemas presentes no tratamento da questão. Esses dilemas precisam ser adequadamente situados em avaliações específicas, que se aprofundem nas especificidades dos gastos setoriais - suas justificativas, racionalidades, "lógicas".

O objetivo deste trabalho é abordar a questão da qualidade do gasto público ou, mais especificamente, do gasto público social do governo central - por meio da avaliação do financiamento orçamentário das chamadas políticas públicas de emprego do Ministério do Trabalho e Emprego (MTE). Para isso, o trabalho divide-se em sete seções, além desta introdução. Nas seções "A qualidade do gasto público" e "A importância dos gastos sociais e previdenciários", são apresentadas algumas das questões mais gerais relacionada ao tema da qualidade 
do gasto e à evolução dos gastos sociais. $\mathrm{O}$ argumento fundamental presente nessas seções é que, embora essas questões gerais tenham grande importância na orientação do debate, elas não podem prescindir de avaliações mais aprofundadas do gasto setorial. A seção "Políticas ativas e passivas de emprego: orçamento no período 20002006" apresenta a evolução do orçamento para as políticas setoriais do MTE, no período 2000-2006, e seus mais importantes dilemas. $\mathrm{Na}$ seqüência, o artigo traz uma avaliação da focalização e do impacto das políticas de emprego, com ênfase no abono salarial PIS/Pasep. A seção seguinte sugere uma agenda para as ações do ministério, com ênfase na melhoria da qualidade do gasto. Ao final, procura enfatizar as principais conclusões do estudo.

\section{A qualidade do gasto público}

A farta literatura disponível permite perceber que o tema da qualidade do gasto público - e, dentro do gasto público, com grande ênfase, o gasto social - é matéria de crescente interesse no País. Esse interesse decorre tanto de fenômenos políticoeconômicos, como o aumento do gasto público primário, das despesas ditas "sociais" e, conseqüentemente, da carga tributária, quanto institucionais, como a retomada das ações de planejamento por meio dos Planos Plurianuais (PPAs) e a adoção da Lei de Responsabilidade Fiscal.

O aumento do gasto público primário do governo central, ao longo dos últimos 15 anos, tem sido forte. Giambiagi (2006), a partir dos dados da STN/MF e $\mathrm{SPE} / \mathrm{MF}$, aponta para um crescimento da ordem de 8,9 pontos percentuais do PIB entre 1991 e 2005, passando de 13,7\% do PIB, em 1991, para 22,6\% do PIB, em 2005. Com pequenas diferenças metodológicas ${ }^{1}$, o trabalho de Almeida e outros (2006) que exclui da análise dos gastos não financeiros as despesas com investimento e as transferências obrigatórias a estados e municípios e detalha as chamadas "outras despesas de custeio e capital" - demonstra que a dinâmica de ampliação do gasto primário do governo central não apenas se manteve nos últimos cinco anos (aumento de 1,6 pp do PIB entre 2001 e 2005), como pode ser considerada, em grande medida, reflexo do aumento das despesas sociais ( $+0,8$ pp do PIB, no mesmo período) e das despesas previdenciárias (+ 0,7 pp do PIB).

Como, além de expandir fortemente seus gastos ao longo dos últimos 15 anos, o governo central também passou a gerar robustos superávits primários desde 1999 , com o objetivo de controlar o aumento da relação dívida pública/PIB, a carga tributária chegou a aproximadamente 37\% do PIB em 2005. Como não poderia deixar de ser, a imposição de uma carga como essa, em um país em desenvolvimento, certamente é responsável pelo maior questionamento da qualidade dos gastos públicos.

Esse questionamento encontrou reflexos institucionais em diversas oportunidades. Duas delas, entretanto, merecem destaque.

A primeira delas deu-se durante a elaboração do PPA 2000-2003, que pôs grande ênfase "nos aspectos relacionados à gestão e, por conseguinte, em um dos seus principais instrumentos, a avaliação". Exatamente por isso, constaram de sua orientação estratégica "diversas menções ao novo estilo de gestão das ações de governo, centrado na melhoria da qualidade do gasto público" (GARCIA, 2001). Essa preocupação está ainda presente nas prioridades estabelecidas no Macroobjetivo $\mathrm{n}^{\circ} 2$ do mesmo 
PPA ("Sanear as finanças públicas"): delas consta "melhorar a qualidade do gasto público mediante o aperfeiçoamento do Sistema de Planejamento, Orçamento, Finanças e Controle".

Muito embora as eventuais deficiências conceituais e de operacionalização desses princípios pudessem ser apontadas (como, ainda em 2001, fazia o mencionado trabalho de Ronaldo Coutinho Garcia), sua presença, central no plano, já refletia o quão importante, política e socialmente, era a preocupação com a qualidade do gasto.

Também em 2000, outro marco institucional importante surgiu, a Lei de Responsabilidade Fiscal - LRF (Lei Complementar $n^{\circ}$ 101/2000). Além de estabelecer normas que limitam gastos com pessoal e o endividamento e forçam o estabelecimento de metas fiscais anuais e de provisão de despesas correntes, a LRF prevê mecanismos de controle de qualidade dos gastos públicos, como o disposto no seu art. $4^{\circ}$, que sustenta que a Lei de Diretrizes Orçamentárias irá dispor de "normas relativas ao controle de custos e à avaliação dos resultados dos programas financiados com recursos dos orçamentos". Dessa forma, a LRF contribuiu para o aumento do espaço dado "às discussões em curso sobre a quantidade e a qualidade do gasto" (Afonso, 2005).

Alguns pontos gerais são perceptíveis para os que acompanham o debate em torno das variações do gasto público não financeiro e de sua qualidade. Valeria aqui chamar a atenção para dois deles.

O primeiro é que avaliações mais gerais da evolução dos gastos públicos podem sublinhar dilemas importantes sobre a qualidade dos gastos - mas, pelo seu caráter necessariamente geral, não chegam a apresentar considerações mais embasadas para esta discussão. Tome-se, por exemplo, o trabalho de Almeida e outros (2006), que retoma um dos principais dilemas (mais do que econômico, político, como adequadamente destacam os autores) da alocação orçamentária, o existente entre as despesas com políticas sociais e previdenciárias, por um lado, e as com investimentos, por outro. Muito embora este seja um dilema central, há toda uma série de

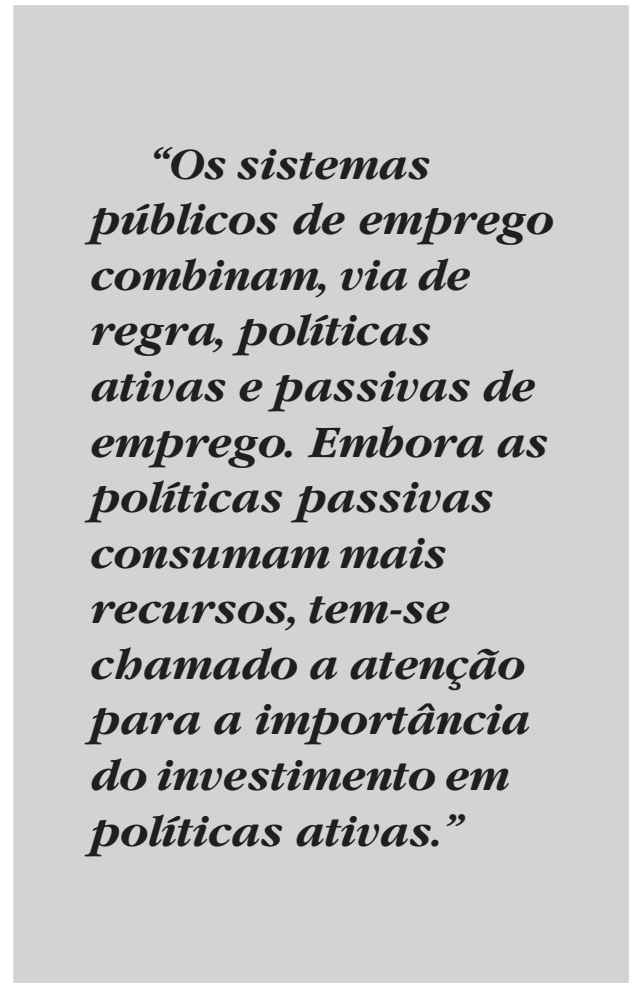

considerações sobre a qualidade das despesas (tanto das ditas "sociais" quanto as voltadas para investimento) que não podem ser reduzidas ao próprio dilema. Permanece aberto o espaço, dessa forma, para discussões mais aprofundadas, como as voltadas para mensurar o grau de efetividade que têm os investimentos ora feitos - ou o nível diferenciado de impacto que políticas sociais concorrentes 
têm, por exemplo, no combate à pobreza ou na diminuição da desigualdade. Essas, mais ainda que as necessárias discussões de cunho geral, são as capazes de dar sustentação às mudanças na alocação orçamentária que representem uma melhoria da qualidade do gasto social. Esse argumento será retomado à frente.

O segundo ponto é o correto destaque que é dado ao custo político das mudanças institucionais necessárias para a melhoria da qualidade do gasto público. Em um país como o Brasil, com inúmeras carências severas - e outras tantas, menos severas, mas mais bem articuladas -, a solução política de equilíbrio após a redemocratização foi dada pela expansão do gasto público nas despesas sociais e previdenciárias, mas não nos investimentos. Qualquer reorientação dessa dinâmica, como destacam corretamente Almeida e outros (2006), "envolve, necessariamente, mudanças institucionais [...] e decisões de elevado custo político”.

\section{A importância dos gastos sociais e previdenciários}

Em anos recentes, certa dose de esforço foi desperdiçada na discussão da importância do gasto social para o gasto público do governo central. Em grande medida, tal desperdício deu-se em torno da afirmação contida no documento apresentado pela SPE/MF (BRASIL/MF, 2003), segundo a qual $2 / 3$ das despesas públicas não financeiras eram compostas pelos chamados "gastos sociais". Com isso, argumentou-se, haveria relativa abundância de recursos para a área social - a carência seria de foco.

A discussão que se seguiu (cf., por exemplo, São Paulo, 2003; BresserPereira, 2003) deu-se exatamente no questionamento da afirmação, especialmente em decorrência da agregação das despesas previdenciárias (tanto as do Regime Geral de Previdência Social quanto as do Regime Próprio dos Servidores do Governo Federal) às chamadas "despesas sociais". Ora, como as despesas previdenciárias somavam, em 2002, 65\% do conjunto das "despesas sociais" (assim consideradas), toda a avaliação dos gastos sociais era fortemente enviesada pelo perfil dos gastos previdenciários. Por esse motivo, Bresser-Pereira (2003) argumentou - não sem razão - que o alegado caráter regressivo do gasto social brasileiro era, na verdade, em razão da inclusão, nesse gasto, dos gastos previdenciários (que seriam regressivos).

Dois fatos, entretanto, escaparam aos críticos. Primeiramente, não se percebeu que, independentemente da caracterização das políticas previdenciárias como "sociais", é o crescimento das despesas com benefícios previdenciários, com benefícios assistenciais e com outras políticas sociais (como as de transferência de renda) que pressiona as despesas não financeiras do governo central, já que não se percebe a ampliação das despesas com investimento (Almeida et al., 2006). Segundo, não se deu a devida importância ao fato de que o documento do Ministério da Fazenda tinha trazido para a linha de frente da discussão, dentro do governo, um importante aspecto da avaliação das políticas sociais, qual seja, o grau de focalização dessas políticas nos mais pobres ${ }^{2}$.

Mais uma vez, entretanto, a presença de importante (e, poder-se-ia dizer, crucial) elemento para a avaliação geral do gasto público (neste caso, a focalização das políticas sociais nos mais pobres) não basta. Com efeito, tal como o dilema entre as despesas com políticas sociais e os 
investimentos precisa ser devidamente qualificado, a abordagem da focalização para as políticas sociais - a despeito da sua óbvia relevância, na medida em que a própria definição de "social" implicaria a necessidade de alcançar os mais pobres também depende, ela mesma, da qualificação que apenas pode ser dada por análises mais específicas do gasto setorial. Há, portanto, aspectos técnicos relevantes que não podem ser descartados.

Dois exemplos podem mostrar claramente como as especificidades do gasto setorial não podem ser desconsideradas. Tome-se, por exemplo, a suposta má focalização do gasto previdenciário apontada nos documentos do Ministério da Fazenda (Brasil/MF, 2003; 2005). Com efeito, os gastos previdenciários parecem beneficiar os mais ricos exatamente pelo fato de que os benefícios previdenciários são levados em conta. À medida que se retiram, do total de rendimentos da população aposentada, os benefícios previdenciários, a população que os recebe torna-se, imediatamente, pobre e fortemente localizada nos dois primeiros décimos da renda per capita (cf. Schwarzer; Paiva, 2003). Em outras palavras, os benefícios previdenciários estão dirigidos a uma população que, se não os recebesse, faria parte dos grupos mais pobres - e, se essa população estiver entre os mais ricos, é exatamente pelo fato de receber os benefícios.

Por outro lado, é de se esperar, no contexto brasileiro, que certos gastos sejam, em alguma medida, regressivos. É o que aponta Bresser-Pereira (2003) com relação aos gastos do governo central com educação, que se concentram na educação universitária e são, "por definição, regressivos". Progressivos seriam os gastos com a educação fundamental e média, feitos majoritariamente por municípios e estados.
Assim, embora certos dilemas e questões centrais (como "investimento $\mathrm{x}$ gastos sociais" ou "focalização das políticas sociais") sejam importantes na avaliação do gasto público, em geral, e do gasto social, em particular, eles devem servir, no máximo, como diretrizes para estudos mais específicos que se voltem para a natureza e a lógica de determinados gastos setoriais. Em outras palavras, a discussão da qualidade dos gastos públicos não pode prescindir da avaliação atenta das políticas públicas por eles financiadas - razão por que os temas da qualidade do gasto e da avaliação de políticas estão intimamente conectados.

Nas seções seguintes, será apresentada uma apreciação dos principais dilemas relativos ao financiamento orçamentário das políticas públicas de emprego financiadas pelo MTE, nos últimos sete anos.

A escolha das políticas públicas de emprego decorre de dois fatores. O primeiro é a importância dos gastos do MTE no volume total dos gastos sociais: programas como o seguro-desemprego e o abono salarial envolvem montantes na casa da dezena de bilhões de reais. O segundo motivo é o fato de que o cenário dos últimos anos, em que vingou grau considerável de restrição orçamentária, vem afetando fortemente a execução de políticas do MTE em um sentido que, em princípio, seria o oposto do tecnicamente desejável. Logo, as políticas de emprego do órgão configuram um caso paradigmático para a discussão da qualidade do gasto.

É preciso destacar que a abordagem aqui utilizada foi a análise orçamentária que reflete a análise do gasto, mas não se confunde com ela. De maneira simplificada, o orçamento estabelece os limites para o gasto, que podem ou não ser efetivados por meio de empenhos, que serão liquidados e 
finalmente pagos - fase que corresponderia mais estritamente ao gasto.

A análise orçamentária, quando se faz um acompanhamento histórico (mesmo de curto prazo, como a deste trabalho), reflete satisfatoriamente a evolução do gasto e, nesse caso, traz pelo menos uma vantagem: permite que o ano de 2006 também seja considerado.

\section{Políticas ativas e passivas de emprego: orçamento no período 2000-2006}

A literatura divide as políticas públicas de emprego em dois tipos.

O primeiro deles é formado pelas políticas passivas, o qual tem como objetivo assegurar um nível mínimo de renda, especialmente para o caso de desemprego ${ }^{3}$, ou reduzir o excesso de oferta de trabalho. A redução da oferta de trabalho dá-se pela antecipação da aposentadoria, pela redução da jornada ou pelos desincentivos a que certos grupos participem do mercado de trabalho. Mas o instrumento que historicamente foi considerado a mais importante política passiva de emprego foi o segurodesemprego (Azeredo; RAMos, 1995).

No caso brasileiro, dois programas se sobrepõem, em grande medida, na função de assegurar um mínimo de renda para o caso de desemprego. O primeiro deles é o Fundo de Garantia do Tempo de Serviço (FGTS), criado ainda na década de 60. Trata-se de um fundo, com contas individuais, em que são depositados $8 \%$ dos rendimentos do trabalhador. Os recursos acumulados podem ser sacados em determinadas situações, entre elas o desemprego não justificado. O FGTS, dada a natureza extra-orçamentária, não será examinado neste trabalho. $\mathrm{O}$ segundo programa, criado na segunda metade da década de 1980, é o seguro-desemprego, financiado com recursos do Fundo de Amparo ao Trabalhador (FAT), que, por sua vez, é mantido fundamentalmente com as contribuições do PIS/Pasep. O benefício varia de um a quase dois salários mínimos, pagos por um período de três a cinco meses.

No País, há ainda uma ação de complementação de renda que também pode ser classificada como política passiva, o abono salarial ${ }^{4}$. Trata-se de um benefício no valor de um salário mínimo, em parcela única anual, devido àqueles trabalhadores com vínculo formal (do setor público ou privado), inscritos no PIS ou no PASEP há, pelo menos, cinco anos, cujo rendimento médio mensal no ano anterior não tenha sido superior a dois salários mínimos.

Por sua vez, as políticas ativas têm como objetivos: aumentar a demanda por trabalho (via, por exemplo, criação de empregos públicos, frentes de trabalho, programas de apoio às micro e pequenas empresas e outras ações), reduzir o chamado desemprego friccional (por meio de ações de intermediação de mão-deobra), combater o desemprego estrutural (utilizando ações de qualificação profissional) e facilitar a inserção ou reinserção de grupos específicos (como o subsídio ao emprego de jovens ou desempregados de longa duração).

Os sistemas públicos de emprego combinam, via de regra, políticas ativas e passivas de emprego. Embora seja regra que as políticas passivas consumam mais recursos, nos últimos anos tem-se chamado a atenção para a importância do investimento em políticas ativas, na medida em que elas fazem maior diferença na possibilidade de o trabalhador desempregado (ou em risco de desemprego) conseguir uma melhor situação no mercado de trabalho. 
Nesse sentido, as Diretrizes da Estratégia Européia de Emprego sugerem: 1) a revisão dos sistemas de proteção social, no que diz respeito aos desincentivos que criam para o trabalho, especialmente dos trabalhadores de menor rendimento; 2) ênfase nas políticas ativas de emprego (sobretudo intermediação de mão-de-obra e qualificação profissional, com serviços "personalizados", na medida do possível) (European Union, 2005). Da mesma maneira, as bem-sucedidas reformas ocorridas na Áustria, na Dinamarca, na Irlanda e na Holanda trataram de fazer um pouco menos "generosos" o segurodesemprego e outras formas de assistência (em termos de reposição salarial e duração) e colocaram ênfase em políticas ativas de emprego (HARASTY, 2004).

Assim, as políticas passivas, necessárias e presentes em todos os Sistemas Públicos de Emprego (SPEs) bem estruturados, devem ser articuladas com as políticas ativas, de maneira a serem potencializados os pesados recursos nelas investidos.

No Brasil, as políticas ativas e passivas de emprego foram, nas últimas décadas, criadas em torno de um SPE, que, em alguma medida, ainda é incipiente e relativamente desarticulado. O tripé básico de políticas passivas e ativas de emprego (seguro-desemprego, qualificação profissional e intermediação de mão-de-obra) começou a se formar ainda na década de 1940, com a criação do Senai e do Senac, as primeiras entidades do que viria a ser o Sistema S. Nos anos 60 surgiu o FGTS. A década de 1970 foi marcada pela criação do Sistema Nacional de Emprego (Sine), responsável pela execução da ação de intermediação de mão-de-obra ${ }^{5}$. No final dos anos 80, surgiu o seguro-desemprego, que, entretanto, só contou com uma fonte sólida de financiamento com a criação do
Fundo de Amparo ao Trabalhador (FAT), em 1990. Finalmente, em 1996 surgia a primeira ação estruturada de qualificação no âmbito do Ministério do Trabalho e Emprego, o Plano Nacional de Qualificação Profissional (Planfor).

Ainda no âmbito do Ministério do Trabalho e Emprego, foram criados, na primeira metade dos anos 90, os Programas de Geração de Emprego e Renda (Proger), de apoio (mediante crédito) a micros e

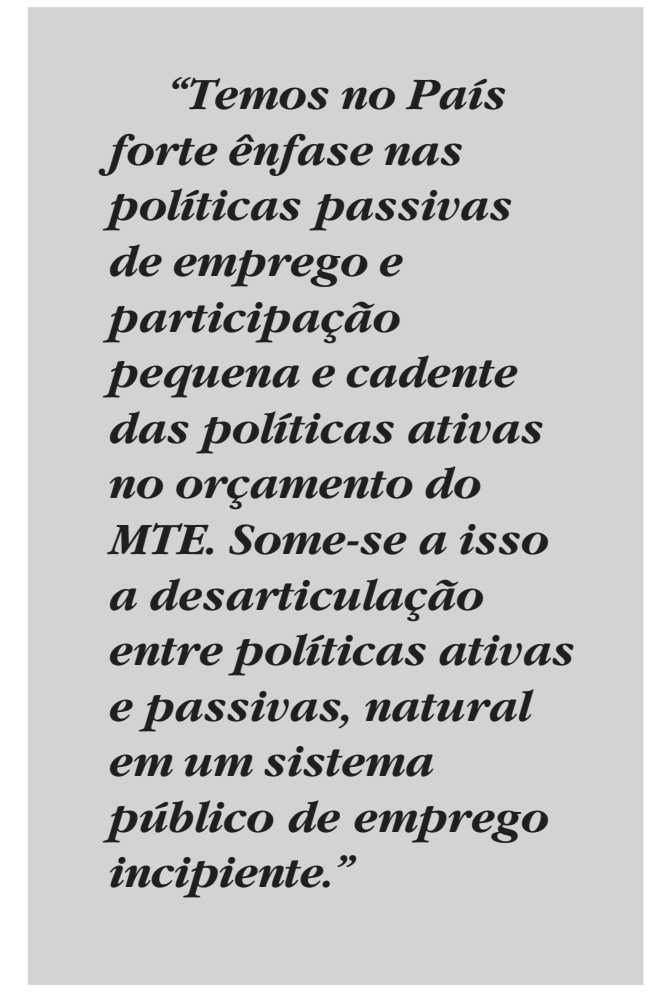

pequenas empresas. Esses programas não serão examinados aqui, dada sua natureza extra-orçamentária.

A comparação entre os valores orçamentariamente destinados a essas políticas abrange, como mencionado anteriormente, o período 2000-2006, considerando as respectivas Leis Orçamentárias Anuais (LOAs). Não serão examinados os valores executados. 
Nos últimos sete orçamentos do MTE, houve um substantivo aumento dos valores destinados às políticas de emprego, que saltaram de quase $\mathrm{R} \$ 5,7$ bilhões em 2000 para quase $\mathrm{R} \$ 12,4$ bilhões (variação nominal de $118,8 \%$ e real de $58,8 \%$, considerando-se o IPCA).

O aumento dos recursos para as políticas de emprego e renda, entretanto, encobre forte disparidade na distribuição dos valores. Assim, no período considerado, os valores reservados para o pagamento do seguro-desemprego aumentaram, em termos nominais, 102,3\% e os do abono salarial, também em termos nominais, $328,8 \%$, com variação na soma dos gastos das duas políticas de 133,6\%. $\mathrm{Na}$ LOA 2006 estão previstos gastos superiores a R $\$ 12$ bilhões com abono e seguro ( $\mathrm{R} \$ 8,99$ bilhões para o seguro e $\mathrm{R} \$ 3,05$ bilhões para o abono).

Os condicionantes do aumento de gastos dessas políticas passivas passam tanto pelo aumento do número de beneficiários quanto pela valorização real do salário mínimo. O número de trabalhadores segurados em 2005 (5,4 milhões) foi $28,4 \%$ maior que o de segurados em 2000 (4,2 milhões); o número de trabalhadores que receberam o abono salarial saltou de 5,6 milhões em 2000 para 9,7 milhões em 2005 (aumento de 72,9\%); por sua vez, o salário mínimo aumentou em termos reais (INPC), entre abril de 2000 e abril de 2006, 42,3\%.

Por sua vez, sempre para o previsto na LOA entre os anos de 2000 e 2006, os valores orçados para a intermediação de mão-de-obra variaram, sempre em termos nominais, apenas $5,5 \%$ e os voltados para a qualificação profissional -75,7\%. Mesmo com a criação do Programa Primeiro Emprego e com as ações executadas pela Secretaria de Economia Solidária, o valor total destinado às políticas ativas em 2006 (intermediação, qualificação profissional, Primeiro Emprego e economia solidária) apresentou, em termos nominais, uma variação nominal de $-33,4 \%$ em relação ao orçado para intermediação e qualificação em 2000. A LOA 2006 prevê recursos da ordem de R \$334,7 milhões para essas três políticas ativas de emprego $(\mathrm{R} \$ 85$ milhões para Intermediação de Mão-de-Obra (IMO); R \$ 102,4 milhões para qualificação; R\$ 134,6 milhões para o Primeiro Emprego; R\$12,9 milhões para economia solidária).

Essas variações podem ser percebidas no Gráfico 1, a seguir. Embora tenha havido um pequeno aporte adicional de recursos entre 2000 e 2001, a trajetória de aplicação de recursos das políticas ativas foi de forte queda no período.

A trajetória ascendente do orçamento total do MTE e do orçamento das políticas passivas mostra claramente o peso dessas políticas no orçamento do órgão. Com efeito, se retirarmos, do orçamento total do MTE na LOA 2006 (R\$ 32,9 bilhões), a Reserva de Contingência do $\mathrm{FAT}^{6}$ (R $\$ 8,3$ bilhões) e o os valores transferidos automaticamente ao BNDES para programas de desenvolvimento econômico ( $\mathrm{R} \$ 7,7$ bilhões), as políticas passivas aqui consideradas formam mais de $71 \%$ dos recursos do orçamento do MTE. Essa participação é relativamente estável ao longo dos anos, no período considerado.

Ao contrário, a participação das políticas ativas de emprego (também retirados os valores da Reserva de Contingência e as transferências ao BNDES), que chegou, em 2001, a 7,6\%, teve trajetória cadente a partir de então, chegando em 2006 a 2\% do orçamento do órgão (cf. Gráfico 2), menor valor da série. 


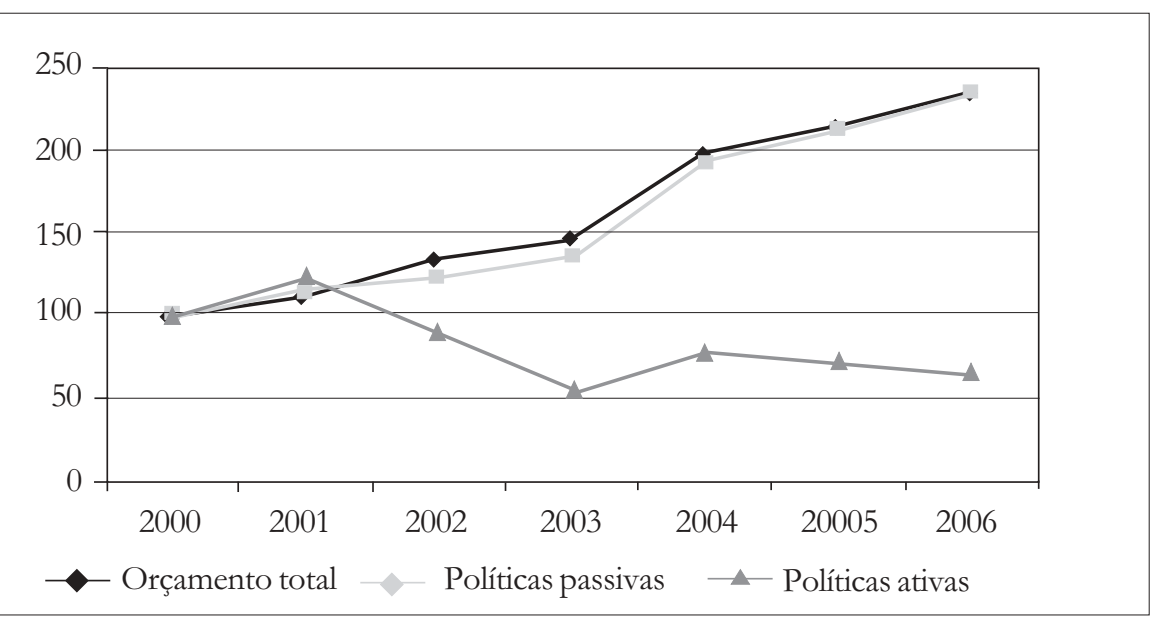

Fonte: LOAs 2000-2006

Gráfico 1: Orçamento nominal do MTE $(2000=100)$

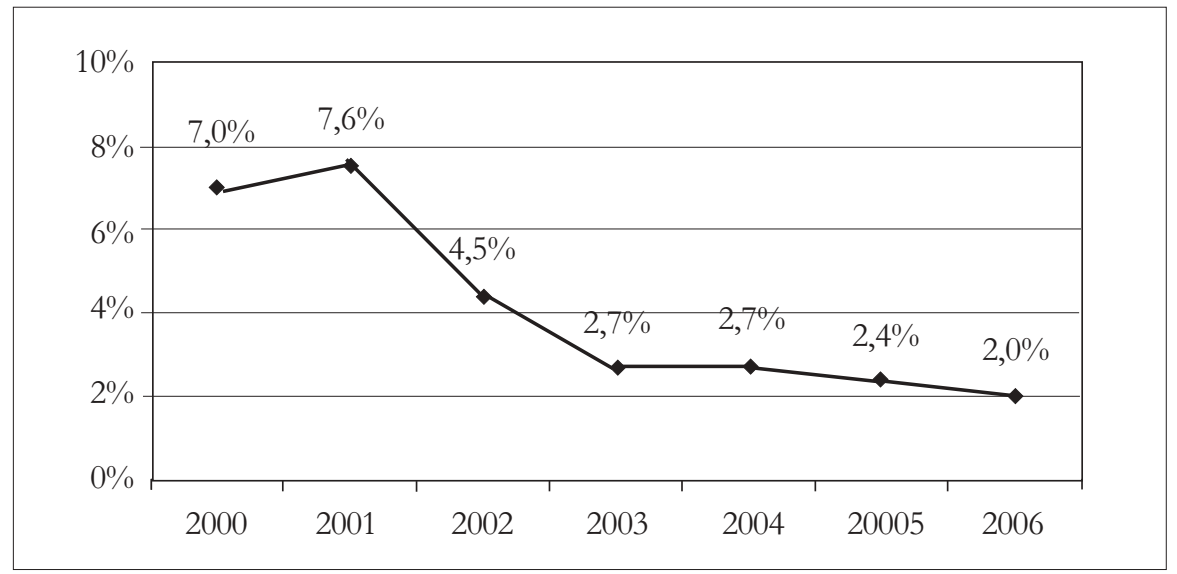

Fonte: LOAs 2000-2006

Gráfico 2: Participação das políticas ativas (intermediação, qualificação e primeiro emprego) no orçamento do MTE (2000-2006)

Como os gastos obrigatórios com as políticas passivas têm trajetória ascendente e os gastos com políticas ativas têm trajetória descendente, a relação tem-se desequilibrado fortemente ao longo dos últimos anos, conforme o Gráfico 3, a seguir.

Essa relação, em que o orçamento das políticas passivas chega a 36 vezes o orçamento das políticas ativas, não encontra paralelo, por exemplo, nos países da Organização de Cooperação e de Desenvolvimento Econômicos (OCDE), que, em geral, têm uma relação gastos com políticas passivas/gastos com políticas ativas menor do que 2,5 - em alguns países, menor mesmo que 1 (cf. Gráfico 4, para exemplos selecionados $)^{7}$.

As limitações orçamentárias têm tido efeito sobre o desempenho das ações de intermediação e qualificação, a cargo do MTE. 


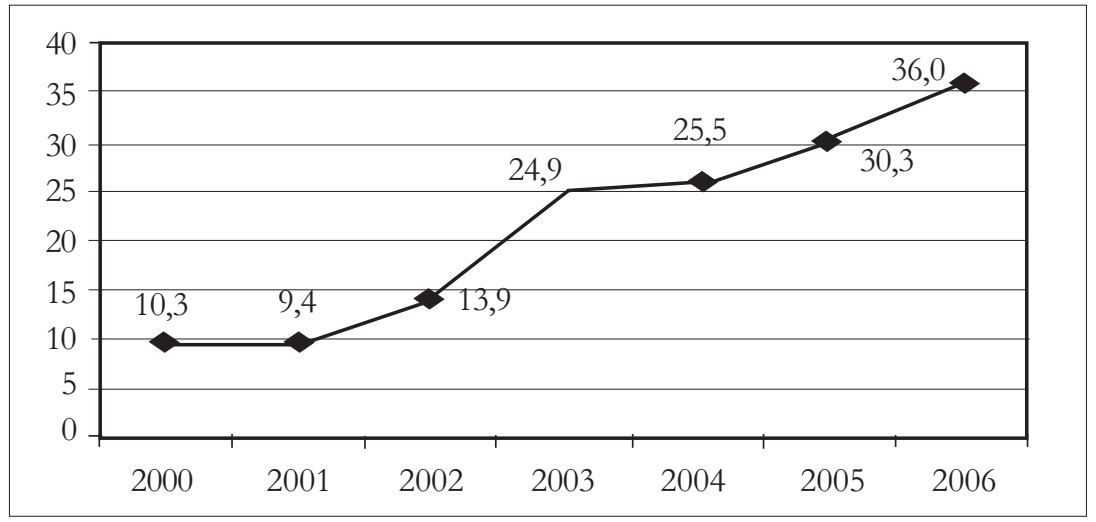

Fonte: LOAs 2000-2006

Gráfico 3: Relação entre orçamento de políticas passivas e orçamento de políticas ativas de emprego

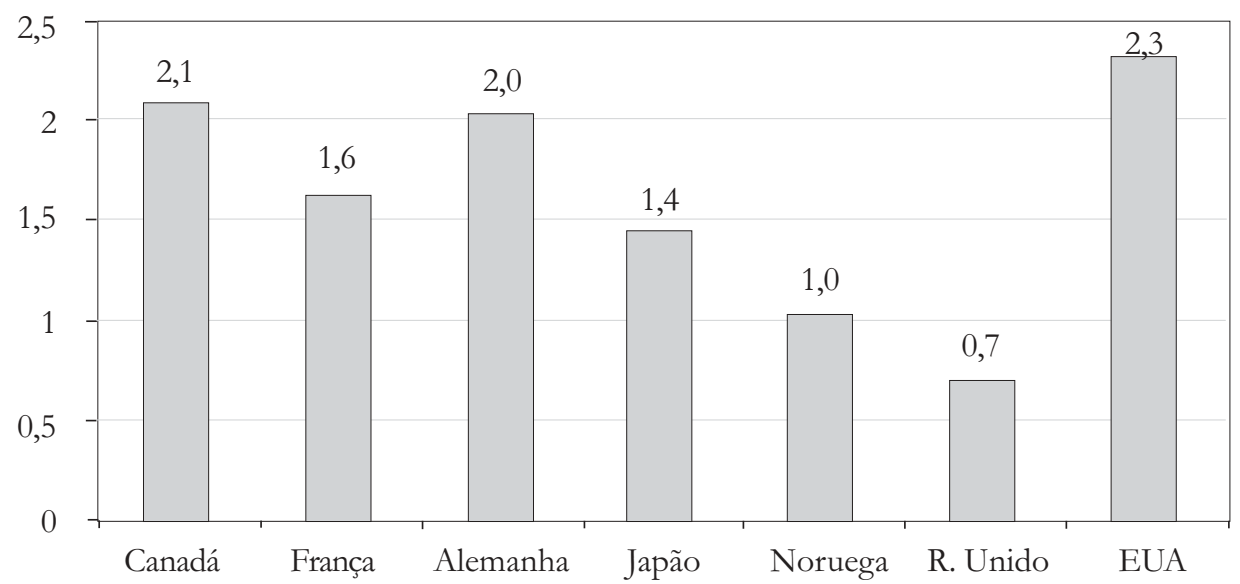

Fonte: OECD Employment Outlook, Statistical Annex. OECD, 2005

Gráfico 4: Relação entre orçamento de políticas passivas e orçamento de políticas ativas de emprego para países da OCDE

No caso da intermediação, houve progressos relativamente constantes no desempenho da ação, entre os anos de 1992 e 2002, entre os quais se destaca que o número de trabalhadores colocados (isto é, que conseguiram emprego formal por meio do Sine) quase decuplicou, saltando de $94,5 \mathrm{mil}$ para 869,7 mil. Nos anos posteriores, entretanto, o desempenho ficou estabilizado, com 844,7 mil trabalhadores colocados em 2003, 888,7 mil em 2004 e 893,7 mil em 2005.
$\mathrm{Na}$ qualificação profissional, os efeitos surgiram ainda antes e foram substantivamente mais fortes. Graças ao contingenciamento orçamentário, já perceptível no ano de 2002, o número de trabalhadores qualificados caiu de 3,6 milhões, em 2001, para 1,8 milhão (Brasil/MTE/Planfor, 2002). A carga horária média dos cursos oferecidos por meio do Plano Nacional de Qualificação do Trabalhador (Planfor) também 
apresentou forte queda, chegando a apenas 57 horas em 2001. A criação do Plano Nacional de Qualificação (PNQ), a partir de 2003, conseguiu reverter a tendência de queda da carga horária média dos cursos: das 61 horas de 2002, chegou-se a praticamente 200 horas em 2005. O número de trabalhadores qualificados, entretanto, diminuiu fortemente, para cerca de $140 \mathrm{mil}$ trabalhadores qualificados/ano, em 2003 e 2004, e 100 mil em 2005 (cf. Gráfico 5, a seguir) ${ }^{8}$.
A focalização das políticas passivas de emprego e o impacto na pobreza e na miséria

\section{Focalização}

O quadro descrito anteriormente é agravado por um fator adicional. As políticas passivas aqui tratadas - seguro desemprego e abono salarial - são, graças ao seu desenho, voltadas apenas aos trabalhadores do mercado formal de trabalho. Graças a isso, e apesar de constarem entre as mais

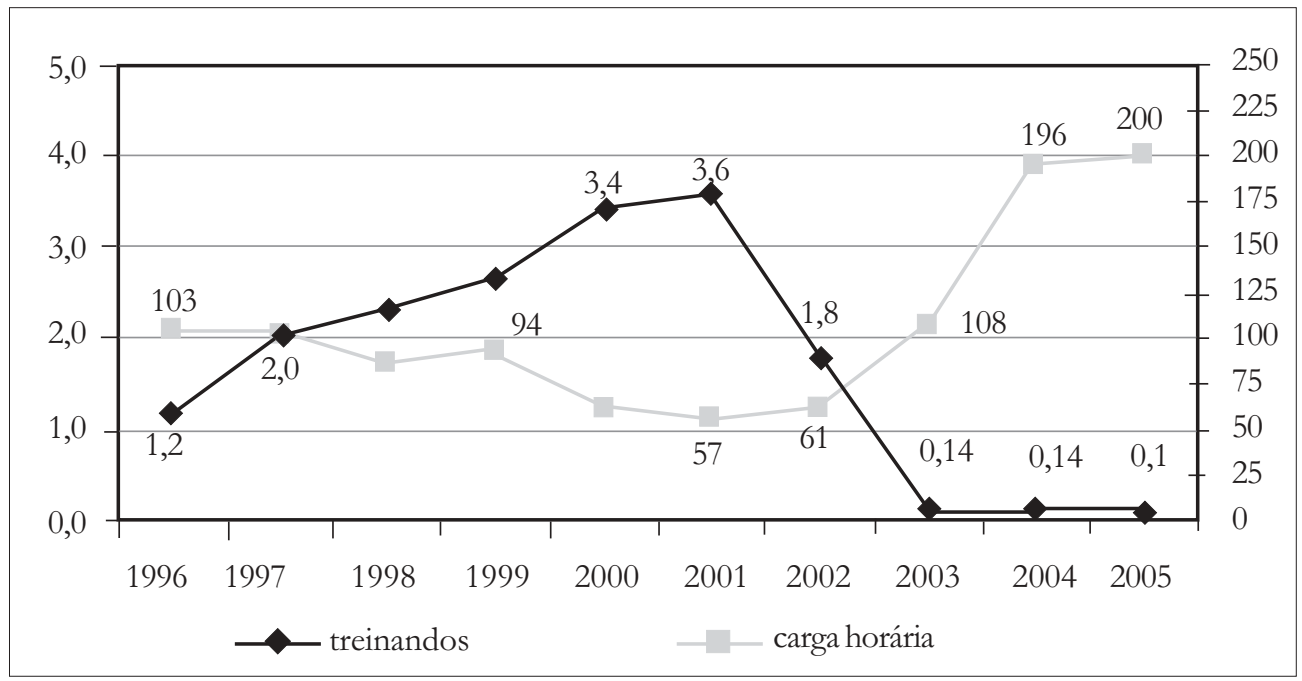

Fonte: MTE

\section{Gráfico 5: Trabalhadores qualificados (em milhões) e carga horária média da qualificação - (Planfor e PNQ / MTE)}

Temos no País, dessa maneira, situação oposta à que seria desejável: forte ênfase nas políticas passivas de emprego (com participação de mais de $70 \%$ no orçamento do MTE); participação pequena e cadente das políticas ativas nesse orçamento (chegando a apenas $2 \%$ em 2006). Some-se a isso a desarticulação entre políticas ativas e passivas, natural em um SPE incipiente mas dificilmente reversível com o quadro orçamentário atual. dispendiosas políticas sociais do governo federal, com recursos previstos para 2006 de mais de $\mathrm{R} \$ 12$ bilhões, elas acabam atingindo uma camada "não pobre" da sociedade brasileira - e não aqueles mais necessitados (Cf. BARros et al., 2001; PASSOS et al., 2002).

Os dados da Pesquisa Nacional por Amostra de Domicílios (PNAD/IBGE), em 2004, permitem que se visualize com clareza a relativa falta de focalização das políticas passivas aqui tratadas, conforme 
os Gráficos 6 e 7, a seguir. Esses gráficos permitem verificar que, como regra, os benefícios do abono salarial e do segurodesemprego atingem, preferencialmente, um grupo não pobre da população: seus beneficiários encontram-se, em comparação com o total da população, concentrados entre o quarto e o oitavo décimo da renda.

No caso do abono salarial, pode-se dizer que a situação é crítica. Primeiramente, pelo fato de que os primeiros décimos de renda são especialmente sub-representados. A chance de encontrar um cidadão que esteja no primeiro décimo de renda, entre os beneficiários do abono salarial, é 6,9 vezes menor que a chance de encontrá-lo no conjunto da população brasileira. A chance de encontrar um cidadão do segundo décimo de renda entre os beneficiários do abono é 1,4 vez menor que a de encontrá-lo no total da população.

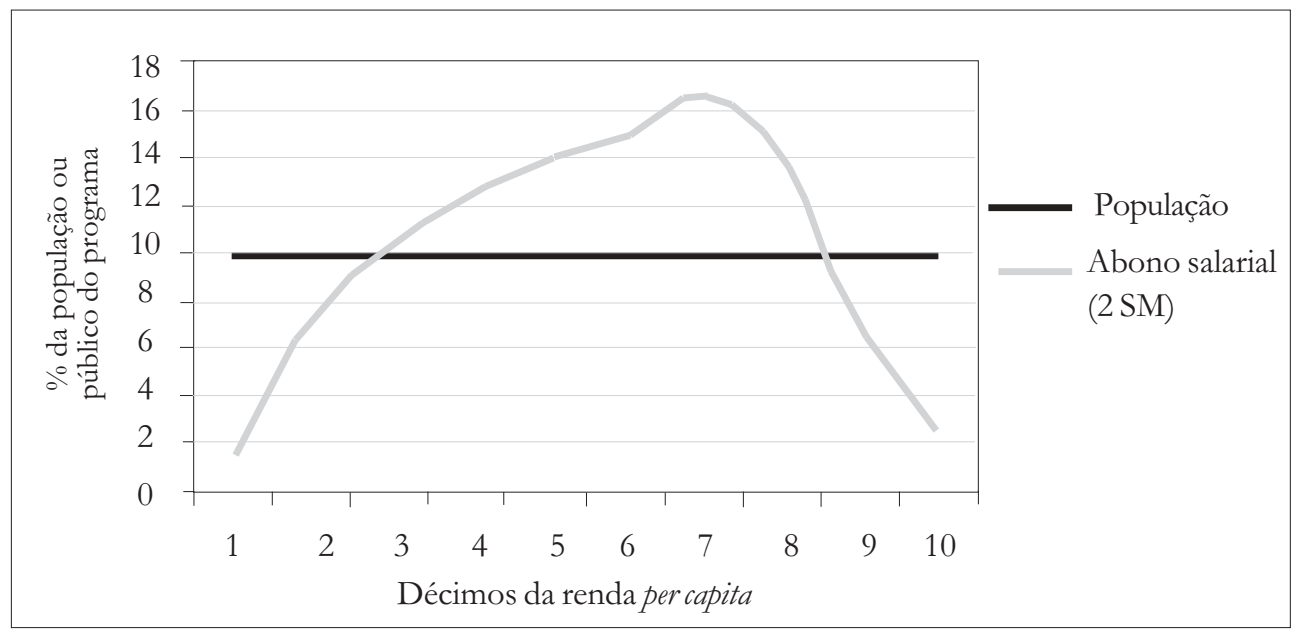

Fonte: Elaboração própria sobre os microdados da PNDAD/IBGE, 2004

Gráfico 6: Público do abono salarial

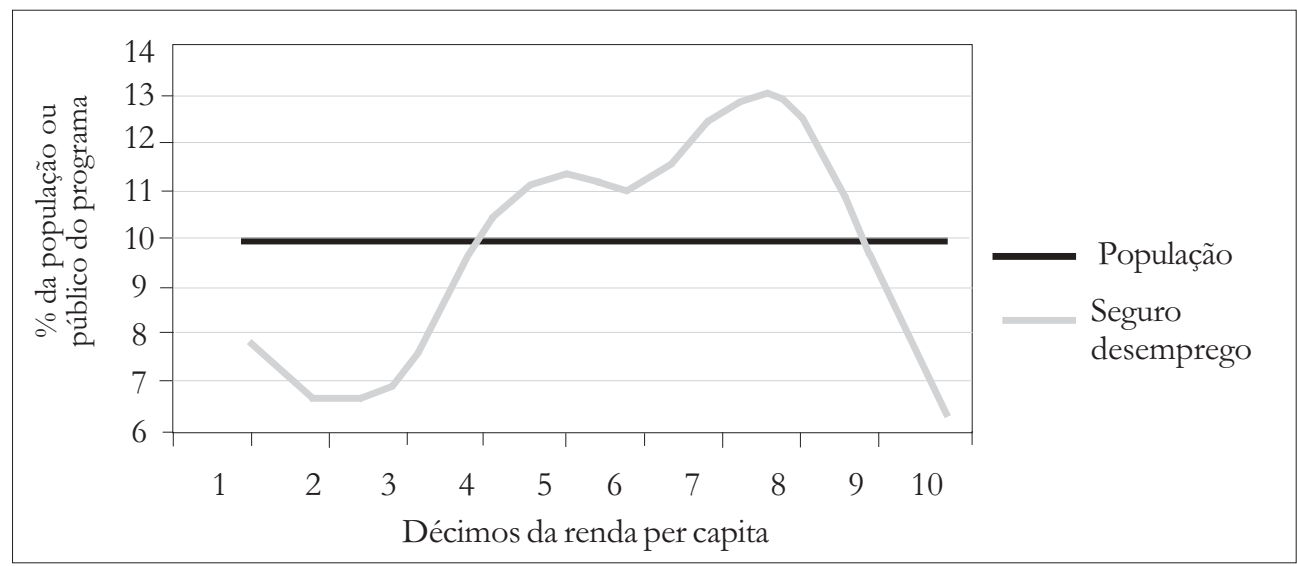

Fonte: Elaboração própria sobre os microdados da PNDAD/IBGE, 2004

\section{Gráfico 7: Público do seguro-desemprego}


Segundo, o abono, ao contrário do seguro, não é um programa direcionado àqueles que sofreram um risco social. Os beneficiários do seguro-desemprego ficaram desempregados - o que significa que, ao menos temporariamente, eles perderam a capacidade de gerar renda. Assim, mesmo que se trate de pessoas situadas nos décimos superiores da distribuição de renda brasileira, houve um evento específico, de ruptura do vínculo empregatício, que levou à perda de renda e ao recebimento do benefício. É exatamente esse o mecanismo das políticas previdenciárias - e sua justificativa.

Isso não ocorre com os beneficiários do abono salarial: eles recebem o valor do benefício a título de complementação de renda. Trata-se, portanto, de algo relativamente paradoxal: um programa de complementação de renda voltado para não pobres, ao custo de $\mathrm{R} \$ 3$ bilhões/ano.

Por outro lado, há evidências sólidas, elaboradas a partir de dados administrativos do próprio MTE, de que as políticas ativas de emprego são muito bem focalizadas: em 2000, 65,7\% dos intermediados e $50,5 \%$ dos qualificados (Planfor) estavam entre os três primeiros décimos de renda da População Economicamente Ativa - PEA (PAssos et al., 2002).

Em outras palavras, além do caráter ativo dessas políticas (que as tornaria preferíveis em relação às políticas passivas), elas também atingem os trabalhadores mais necessitados de políticas sociais.

\section{Impacto na pobreza e miséria}

Graças à má focalização, é de se esperar que o impacto do abono salarial na diminuição da pobreza e da miséria seja baixo, quando comparado com políticas mais bem focalizadas. Essa é a conclusão a que chega o Banco Interamericano de
Desenvolvimento (BID), que vê no abono um exemplo de programa social não projetado para maximizar o impacto na redução da pobreza (INTER-AMERICAN Development Bank, 2004).

Para avaliar comparativamente o impacto do abono salarial na diminuição da pobreza e da miséria ${ }^{9}$, foram realizados dois exercícios, que buscam mensurar o impacto do abono e o impacto de um tipo de política tido como efetivo para a redução da pobreza e da miséria: o dos programas de transferência de renda com condicionalidades - ou programas do tipo "bolsa" (que, no âmbito do governo federal, foram unificados, no início de 2004, no Programa Bolsa Família ${ }^{10}$ ). Esses exercícios utilizaram os dados da PNAD 2004 e consistiram na adição de um valor arbitrário ( $\mathrm{R} \$ 20,00$ por mês, valor aproximado do benefício do abono salarial em 2004 ( $\mathrm{R} \$ 260,00)$ dividido pelo número de meses) para as famílias beneficiárias: 1) do abono salarial e 2) dos programas do tipo "bolsa"11. O exercício, portanto, pretende mensurar o impacto que teria, na pobreza e na miséria, a distribuição adicional de um valor arbitrário ( $\mathrm{R} \$ 20,00 / \mathrm{mês}$ ) aos beneficiários dos dois tipos de programa.

Para o abono, foram considerados beneficiários os trabalhadores com carteira de trabalho assinada ou servidores públicos, com renda de até dois salários mínimos. Como não há a informação dos que estão inscritos no PIS/Pasep por um período mínimo de cinco anos, optou-se por considerar os trabalhadores com pelo menos seis anos de experiência no mercado de trabalho ${ }^{12}$.

Com essa característica, foram selecionados 12,9 milhões de trabalhadores que passariam a receber o abono salarial, com 
um custo anual (considerado o valor anual dos $R$ \$ 20,00/mês, isto é R $\$ 240,00 / a n o)$ de $R \$ 3,1$ bilhões. O exercício de acrescentar $\mathrm{R} \$ 20,00$ ao rendimento mensal desses trabalhadores fez com que, entre eles e seus familiares, cerca de 757,9 mil pessoas ultrapassassem a linha da pobreza e outras 238,9 mil deixassem a miséria.

Para as "bolsas", foram considerados os beneficiários que responderam afirmativamente às variáveis da PNAD 2004 voltadas para detectar beneficiários de programas de transferência de renda. O exercício consistiu em repassar os mesmos R \$20,00 para esse público e verificar quais seriam os impactos na pobreza e miséria.

Nesse exercício, cerca de 5,9 milhões de famílias seriam beneficiadas, a um custo de anual de $\mathrm{R} \$ 1,4$ bilhão. Muito embora o número de beneficiários e o custo fossem substantivamente menores $(53,8 \%$ menos do que o estimado no exercício anterior, com os beneficiários do abono salarial), os resultados, em termos de impacto na pobreza e miséria, seriam surpreendentes: aproximadamente 502,6 mil pessoas deixariam a linha da pobreza (número apenas 33,7\% inferior ao resultado do abono) e 780,4 mil deixariam a linha da miséria (226,7\% superior ao resultado do abono).

Em outras palavras, no exercício aqui realizado, com apenas $46,2 \%$ dos recursos aplicados ao público do abono, ter-se-ia, com a focalização existente em 2004 nos programas do tipo "bolsa", um impacto na redução da miséria substantivamente superior e um impacto na redução da pobreza apenas pouco inferior. Os resultados desses exercícios são apresentados nas Tabelas 1 e 2 , a seguir.

Tabela 1: Exercício - Redução no número de pobres e miseráveis pela aplicação de $\mathbf{R} \$ 20,00 /$ mês (adicionais) para beneficiários do abono e dos programas tipo "bolsa" (2004)

\begin{tabular}{l|l|l|l}
\hline Impacto & Abono & "Bolsas" & "Bolsas"/abono \\
\hline na pobreza & 757.973 & 502.619 & $-33,7 \%$ \\
\hline na miséria & 238.912 & 780.416 & $226,7 \%$ \\
\hline
\end{tabular}

Fonte: Elaboração própria sobre os microdados da PNAD 2004.

Tabela 2: Exercícios - Custo anual

\begin{tabular}{l|c|c|c}
\hline Custo & $\mathbf{N}^{o}$ de beneficiários & Custo ind./ano (R\$) & Custo total (R\$) \\
\hline Abono* & 12.921 .968 & 240 & 3.101 .272 .320 \\
\hline Bolsa & 5.972 .457 & 240 & 1.433 .389 .680 \\
\hline
\end{tabular}

Fonte: Elaboração própria sobre os microdados da PNAD 2004.

* No caso do abono, a estimativa feita com base nos dados da PNAD superdimensiona o número de beneficiários em relação aos números reais. No calendário que vai de julho de 2003 a junho de 2004, foram, de fato, identificados 8,3 milhões de beneficiários e pagos 7,8 milhões de benefícios. Cf. nota 11. 


\section{Uma agenda para as políticas públicas de emprego}

Resumidamente, o quadro atual das políticas orçamentárias de emprego e renda do Ministério do Trabalho e Emprego é o seguinte:

- queda no orçamento das políticas ativas de emprego (intermediação, qualificação profissional, e, a partir de 2003, Primeiro Emprego e Economia Solidária), com variação nominal negativa, entre 2000 e 2006, de 33,4\%;

- forte ênfase nas políticas passivas de emprego (seguro-desemprego e abono salarial, que consumirão mais de $\mathrm{R} \$ 12$ bilhões em 2006, aumento nominal de 133,6\% em relação a 2000), exatamente o oposto do que seria desejável;

- variação dos gastos com políticas passivas condicionada ao aumento do valor do salário mínimo - o que explica, ao menos em parte, a forte variação real nos valores orçados para o seguro-desemprego e o abono salarial nos últimos sete anos;

- dispêndio das políticas passivas concentrado em segmento não pobre da população e com baixo impacto na pobreza (também o oposto do que seria aparentemente desejável).

O contexto orçamentário do governo federal não possibilita imaginar melhora significativa desse quadro em curto prazo. Com efeito, são justamente as fortes restrições orçamentárias, resultantes da necessidade de manutenção de elevado superávit primário e de contenção do gasto público não financeiro, que têm como efeito a queda no volume de recursos investidos nas chamadas políticas ativas de emprego e renda.

Em um quadro como esse, parecem ser pouco proveitosas as alternativas correntes que, sem se aprofundarem na avaliação efetiva da qualidade do gasto, pretendem antes assegurar, pela vinculação orçamentária, determinado nível de gasto. Essa é, por exemplo, a proposta que consta no documento do II Congresso do Sistema Público de Emprego: nela, sugere-se que se assegure "no mínimo, 8\% (oito por cento) da arrecadação primária do FAT para a cobertura orçamentária do conjunto das funções do Sistema Público de Emprego, exceto para as despesas obrigatórias já previstas na Constituição Federal e em legislação específica (Seguro-Desemprego e Abono Salarial)" (Brasil/MTE, 2005).

Em face de propostas como essa, parece ser bastante justificável a resistência dos Ministérios da Fazenda e do Planejamento, Orçamento e Gestão à vinculação de recursos. No caso do MTE, qualquer proposta de vinculação de recursos para políticas ativas de emprego e renda seria recebida, muito provavelmente, com resistência ainda maior que a habitual - já que as políticas passivas, que representam mais de $70 \%$ do orçamento do órgão, são despesas obrigatórias, fortemente influenciadas pela variação do salário mínimo e, por isso, tiveram aumento real significativo nos últimos anos.

O quadro não é reversível em curto prazo, mas as eleições deste ano (2006) abrem espaço para que uma verdadeira agenda seja elaborada para o MTE, agenda que traga uma proposta de solução para a questão orçamentária e, ao mesmo tempo, seja técnica e administrativamente ousada. Apresentam-se, aqui, algumas linhas que poderiam guiar essa agenda.

A contradição que marca a situação atual é que não se vê possibilidade de vinculação de recursos para as políticas ativas e, ao mesmo tempo, assiste-se a uma escalada das despesas com as políticas passivas, vinculadas ao valor do salário 
mínimo, criando um desequilíbrio pouco produtivo para as políticas de emprego.

A principal marca dessa contradição é a manutenção do programa do abono salarial nos moldes atuais, que tem natureza de complementação salarial para trabalhadores, em princípio, empregados; não atinge com efetividade os membros dos quatro primeiros décimos da renda per capita do País; e tem, em 2006, despesa prevista superior a $\mathrm{R} \$ 3$ bilhões (aumento de $328 \%$ em relação ao orçado para 2000).

Em resumo, a situação atual, do ponto de vista técnico, administrativo e orçamentário, parece ser a pior possível.

Abrem-se, dessa maneira, duas possibilidades, vantajosas técnica, administrativa e orçamentariamente: a de negociar a eliminação do abono salarial, ou sua restrição a um grupo menor de trabalhadores, em troca da vinculação do valor real de despesas com políticas ativas de emprego, realizadas pelo ministério, nos níveis atualmente gastos com o abono salarial. Trata-se, obviamente, de matéria politicamente complexa, que depende de alteração constitucional e de disposição política e forte articulação legislativa de governo em início de mandato. Como bem destacam Almeida e outros (2006), mudanças institucionais como essas envolvem alto custo político.

Tecnicamente haveria:

1) a eliminação ou restrição de um programa de complementação de renda pouco efetivo no combate à pobreza;

2) um brutal reforço nos investimentos em políticas ativas, que permitiria a condução de programas fortes e extremamente consistentes de qualificação profissional e intermediação de mão-deobra, equilibrando a execução de políticas passivas e ativas do sistema público de emprego brasileiro. Essas políticas ativas teriam, ainda, a vantagem adicional de chegar a todos os trabalhadores - e, a julgar pelo desempenho histórico dessas ações, com ênfase naqueles situados nos primeiros décimos da distribuição de renda ${ }^{13}$.

A eliminação do abono permitiria o deslocamento de recursos da ordem de R\$ 3 bilhões para políticas ativas de emprego. Caso não se deseje eliminar o benefício do abono salarial, sua restrição a um número menor de trabalhadores poderia dar-se pela limitação àqueles que recebem até um salário mínimo de rendimento médio no ano ${ }^{14}$. Essa restrição reduziria em aproximadamente $75 \%$ o número de participantes ${ }^{15}$, com redução equivalente na despesa (já que o benefício é fixo por participante) - o que deixaria, em valores da LOA 2006, um orçamento para as políticas ativas de aproximadamente $\mathrm{R} \$ 2,3$ bilhões.

Não se deve confundir a eliminação ou restrição do abono como perda de direitos dos trabalhadores: com efeito, os recursos continuariam a ser despendidos com políticas voltadas para os trabalhadores - mas políticas mais efetivas (à medida que aumentam sua capacitação e auxiliam na busca por novo emprego) e mais focalizadas (pois são voltadas para trabalhadores com faixa de renda inferior).

No caso da restrição do abono aos trabalhadores que receberam em média até um salário mínimo por mês no ano anterior, além do reforço no orçamento das políticas ativas e da redução do volume orçamentário atrelado à variação do mínimo, haveria uma melhora da focalização do abono salarial nos trabalhadores mais pobres. No Gráfico 8, a seguir, percebe-se que, com a restrição do pagamento do benefício àqueles que recebem até um salário mínimo de rendimento 


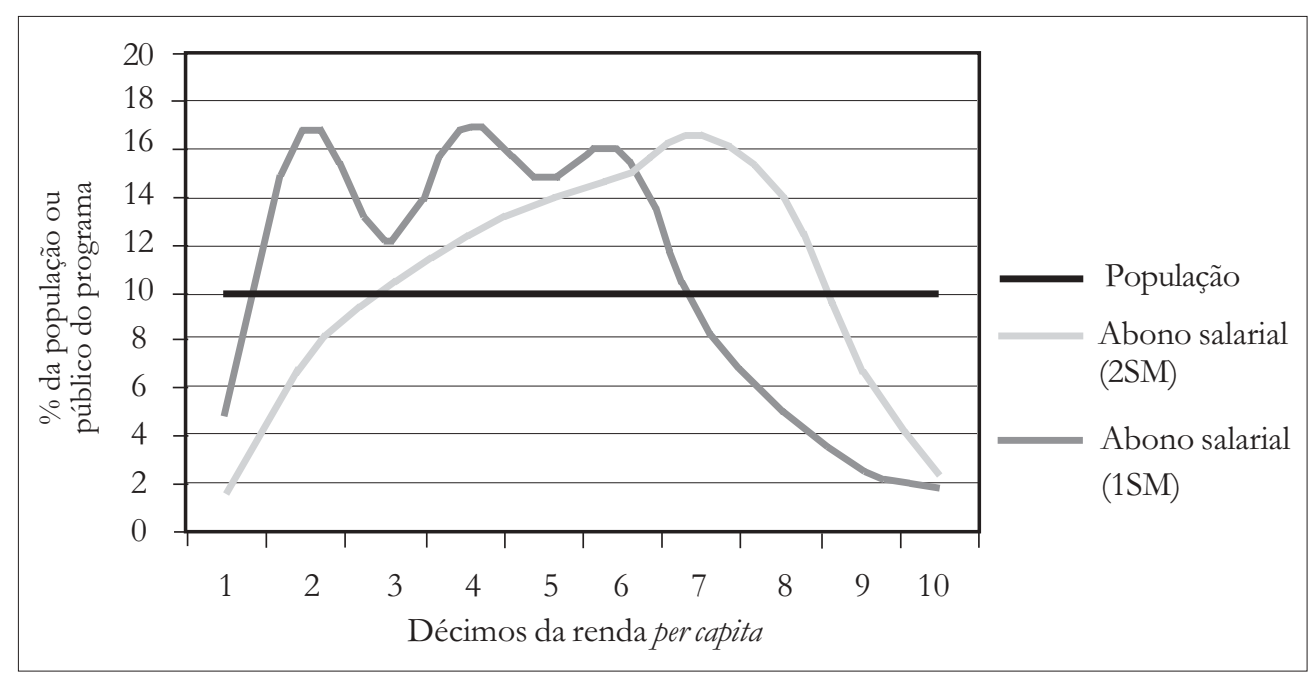

Fonte: Elaboração própria sobre os microdados da PNDAD/IBGE, 2004

\section{Gráfico 8: Público do abono salarial}

médio no ano, haveria claro deslocamento do público do abono salarial na direção dos primeiros décimos de renda.

Com a redução, o percentual dos beneficiários do abono entre os $40 \%$ mais pobres aumentaria de $31,2 \%$ para $50,8 \%$. Embora os membros do primeiro décimo do rendimento per capita ainda continuassem sub-representados (mais uma vez em função do fato de os $10 \%$ mais pobres terem baixa participação no mercado formal de trabalho, para o qual o abono se volta), os $40 \%$ mais pobres passariam a estar sobre-representados entre os beneficiários (seriam 50,8\% dos participantes) - diferentemente do que ocorre hoje.

Administrativamente, em qualquer das duas opções, o volume adicional de recursos voltado para as políticas ativas permitiria:

1) a articulação de políticas ativas e passivas - tema que, não obstante a atenção que tem merecido da atual gestão do MTE, objetivamente vem avançando pouco $^{16}$. Deve-se notar que a articulação entre as políticas é fundamental não apenas pelo melhor aproveitamento dos dispendiosos recursos investidos no segurodesemprego, mas também pela sua redução, à medida que: a) trabalhadores melhor qualificados terão menor rotatividade no trabalho, requisitando menos o benefício; b) um eficiente trabalho de reinserção no mercado de trabalho, por meio da intermediação de mão-de-obra, faz com que caia o número médio de parcelas do seguro usufruídas.

Finalmente, do ponto de vista fiscal, a vinculação das despesas reais com políticas ativas de emprego, nos níveis que seriam economizados com a eliminação ou a restrição do abono salarial, representaria uma desvinculação dessas despesas em relação às variações reais do salário mínimo. Em outras palavras, embora a vinculação do valor real de despesas específicas crie uma compreensível resistência por parte da equipe econômica de qualquer administração do governo federal, deve-se destacar que o resultado final seria amplamente vantajoso em longo prazo. 
Ao programa aqui esboçado deveriam ser incorporados outros elementos, relativos ao Sistema Nacional de Emprego e à qualificação profissional, como:

1) a indução à focalização da ação de intermediação de mão-de-obra nos trabalhadores com maiores dificuldades de inserção e reinserção no mercado de trabalho (nos moldes propostos pela Resolução CODEFAT no 318/2003);

2) a elaboração de sistema efetivo de controle e supervisão para a atividade de intermediação de mão-de-obra realizada pelo Sine, até hoje inexistente;

3) avaliação de eficiência e impacto como elementos norteadores das políticas de intermediação de mão-de-obra e qualificação profissional.

Finalmente, uma agenda independente precisaria ser elaborada para tornar o seguro desemprego uma política mais ativa. A complexidade da questão faz com que essa agenda não possa ser abordada neste trabalho, mas certamente pontos como a utilização dos recursos do seguro como subsídio ao emprego, o fortalecimento da bolsa qualificação, o pagamento único para financiamento de micronegócios devem constar dessa agenda ${ }^{17}$.

É necessário ressaltar que os problemas enfrentados pelo MTE, na execução das políticas de emprego, não se resumem à falta de recursos para as políticas ativas. Mais, a existência de montante significativo de recursos para as políticas ativas, associado à vinculação de sua despesa, tornaria mais visíveis os variados problemas operacionais ora existentes e, dessa maneira, mais fáceis suas soluções.

Seja como for, essa seria uma oportunidade para o equacionamento desses problemas operacionais e o desenvolvimento de extensa agenda de melhoria da qualidade do gasto público em políticas de emprego - agenda essa que, neste momento, é inexeqüível.

\section{Conclusão}

O debate relativo à melhora do gasto público em geral - e, com destaque, do gasto social - tem tido espaço crescente. Contam, para isso, o aumento do gasto e da carga tributária, nos últimos anos, por um lado; e a existência de mecanismos institucionais que colocam ênfase no tema, como o PPA e a LRF.

Muito embora os grandes dilemas associados à questão da melhora do gasto sejam importantes, argumentou-se, neste trabalho, que a discussão mais específica e conseqüente do gasto público não pode prescindir da avaliação dos gastos setoriais - razão pela qual a avaliação das políticas públicas é instrumento fundamental e intimamente associado à melhoria do gasto público.

O trabalho demonstrou que o quadro atual das políticas públicas de emprego é crítico, dado o forte desequilíbrio existente entre os investimentos em políticas passivas (seguro-desemprego e abono salarial cujo orçamento, de despesa obrigatória, é crescente) e em políticas ativas (especialmente intermediação de mão-de-obra e qualificação profissional - que têm enfrentado forte restrição orçamentária). $\mathrm{O}$ orçamento das políticas passivas tem crescido fortemente em relação ao orçamento das políticas ativas, criando desequilíbrio inadequado para o bom funcionamento do sistema público de emprego.

As políticas passivas de emprego aqui examinadas têm, ademais, a característica de serem voltadas para o mercado formal de trabalho. Com isso, sub-representam, 
entre seus beneficiários, a parcela da população que está nos primeiros décimos da distribuição de renda no País e superrepresentam a que está entre o quarto e o oitavo décimo da distribuição de renda.

A eliminação do abono salarial - ou sua restrição, por exemplo, àqueles que receberam até um salário mínimo por mês, em média, no ano anterior -, associada à vinculação desses recursos aos gastos com políticas passivas, parece ser vantajosa do ponto de vista fiscal, técnico e administrativo - embora seja matéria politicamente complexa.

Do ponto de vista fiscal, haveria uma clara vantagem: parcela substantiva do orçamento do MTE não estaria mais atrelada à variação do salário mínimo, mas apenas à variação da inflação. A proposta, além disso, abriria espaço para a adoção de ampla e ousada agenda para o sistema público de emprego no Brasil, marcada tecnicamente pelo reforço das políticas ativas (mais bem focalizadas nos grupos mais necessitados da população) e administrativamente pela possibilidade de integração entre as várias ações de emprego existentes no País, gerando substantiva melhoria da qualidade do gasto setorial.

(Artigo recebido em agosto de 2006. Versão final em outubro de 2006)

\section{Notas}

* Agradeço a Alessandro Passos, Graziela Ansiliero, Leonardo Neves e Tiago Falcão pelos comentários feitos a uma versão anterior do trabalho. Desnecessário dizer, as deficiências ainda existentes são de minha inteira responsabilidade

1 Giambiagi (2006) trabalha com dados da STN, de valores pagos, portanto. Por sua vez, Almeida, Giambiagi e Pessoa (2006) utilizam, para a avaliação da dinâmica dos gastos sociais, os empenhos liquidados. Como os próprios autores sustentam, isso não mina a possibilidade de comparação entre esses dados.

2 Vários trabalhos, anteriores ao documento do Ministério da Fazenda, deram ênfase à focalização das políticas sociais, como os de Barros et al. (2001) e Passos et al. (2002). O documento do Ministério da Fazenda, entretanto, trouxe a perspectiva para dentro do governo federal.

3 Como tal, o seguro-desemprego também pode ser considerado uma política previdenciária, na medida em que tem como preocupação fundamental a manutenção de determinado nível de renda, em caso de ocorrência de risco social específico (o desemprego).

5 Para uma exposição detalhada da criação do Sine, cf. Borges (2003).

6 A Reserva de Contingência - ou Reserva Mínima de Liquidez - do FAT é o valor que permite, grosso modo, o pagamento dos benefícios do seguro-desemprego e do abono salarial por um período de seis meses.

No cálculo da relação entre políticas passivas e políticas ativas, no Brasil, dois fatores adicionais precisam ser considerados. Primeiramente, devem-se considerar os valores dos saques do FGTS em caso de desemprego. Uma projeção linear, com base nos saques realizados entre 2002 e 2004, indica a necessidade de se somar ao numerador um valor da ordem de $\mathrm{R} \$ 15,87$ bilhões. Segundo, deve-se levar em conta que parte substantiva de recursos públicos voltados para qualificação profissional, no Brasil, 
não passa pelo MTE, mas pelas instituições do Sistema S. Para se somar ao denominador, assim, podem-se tomar como proxy do valor aplicado pelo Sistema $S$ em qualificação profissional os valores repassados pela Receita Previdenciária ao Sistema S (que, em 2004, foram de R $\$ 4,02$ bilhões - ou $\mathrm{R} \$ 4,2$ bilhões, com correção da inflação de 2005). Levando-se em conta esses números, ainda assim a relação entre o orçamento das políticas passivas e das políticas ativas é de 6,4 - relação ainda muito superior ao encontrado nos países da OCDE, com pelo menos três agravantes: sobreposição entre FGTS e seguro-desemprego; completa falta de articulação entre as políticas passivas, gerenciadas pelo MTE, e as ações de qualificação do Sistema S; nos gastos do Sistema S não há recursos para a intermediação de mão-de-obra - justamente a ação que, no Brasil, é a porta de entrada do sistema público de emprego e que, portanto, permite a articulação de suas políticas.

8 Devem-se registrar algumas diferenças entre o Planfor e o PNQ na consolidação dos resultados. O Planfor considerava como indicador os "treinandos", que traduziam a quantidade de inscritos nos cursos. O PNQ considera como indicador os "educandos" que são efetivamente concluintes dos cursos de qualificação. Sobre os números do Planfor, assim, pode-se aplicar uma evasão média de 5\% - insuficiente, entretanto, para que a extensão dos programas possa ser comparada.

9 Pobreza foi, aqui, definida como rendimento domiciliar per capita inferior à metade do salário mínimo vigente. Como, nesta seção, foi utilizada a PNAD 2003, foram utilizados o valor de $\mathrm{R} \$ 120,00$, metade dos $\mathrm{R} \$ 240,00$ vigentes como salário mínimo nesse ano. Pelo mesmo motivo, a miséria foi definida como rendimento domiciliar per capita inferior ao valor de $1 / 4$ do salário mínimo (isso é, ao valor de $\mathrm{R} \$ 60,00$ ).

${ }^{10}$ Cf. Lei no 10.836, de 9 de janeiro de 2004.

11 Foram utilizados os dados do suplemento da PNAD 2004 relativos aos programas sociais, considerando como beneficiários dos programas do tipo "bolsa" aqueles que declararam receber um dos seguintes benefícios: o "bolsa família", o "cartão alimentação", o "bolsa alimentação", o "bolsa escola".

12 A "experiência" foi inferida por meio da diferença entre a idade do morador e sua entrada no mercado de trabalho. Esse último critério superdimensiona o público do abono - uma vez que nem todos os trabalhadores que têm seis anos de "experiência" no mercado de trabalho (assim calculada) se mantiveram, durante todo esse período, no mercado formal. Com efeito, no calendário que vai de julho de 2003 a junho de 2004, foram identificados 8,3 milhões de trabalhadores com direito a receber o abono e pagos 7,8 milhões de benefícios, enquanto no exercício aqui realizado foram encontrados cerca de 11,5 milhões de possíveis beneficiários. Esse superdimensionamento, entretanto, não traz maiores problemas, por dois motivos: primeiramente, o objetivo não é aproximar-se do número efetivo de trabalhadores beneficiários do abono salarial, mas ter uma idéia do impacto que determinada soma de recursos teria sobre esse público; segundo, não há risco do superdimensionamento reduzir a projeção do impacto do programa na pobreza. Ao contrário, é de se esperar que o critério aqui adotado considere um público menos bem estabelecido no mercado formal que o público do abono - o que maximizaria o impacto do programa na pobreza e na miséria.

13 O relatório do Banco Mundial (The World Bank, 2002) ressalta o fato de que, no País, os trabalhadores estão sujeitos a excessiva insegurança. Essa é uma característica típica do mercado de trabalho brasileiro, graças ao fato de que os programas de suporte de renda no Brasil voltam-se apenas para trabalhadores formais. Assim, o fortalecimento das políticas ativas, ainda que ao custo da redução de uma política passiva como o abono, beneficiaria os trabalhadores mais pobres justamente os que enfrentam maior insegurança no mercado de trabalho.

${ }^{14}$ Embora o salário mínimo seja o menor rendimento para os trabalhadores formais, o fato de o trabalhador inscrito no PIS/Pasep poder estar desempregado durante parte do ano faz com que o rendimento médio anual possa ser inferior ao salário mínimo.

15 Estimativa feita com base na PNAD/IBGE 2003. 
16 Uma das principais preocupações do II Congresso do Sistema Público de Emprego é, justamente, o da integração das políticas de emprego. O documento que registrou as resoluções do congresso destaca que a "redução expressiva dos recursos destinados" ao SPE vem "dificultando o processo de integração" das ações de emprego. Cf. MTE (2005).

17 Sobre o tema, cf. Neves (2003) e Brasil/MTE (2003).

\section{Referências bibliográficas}

Afonso, José R. R. “5 Anos de LRF”. Seminário Transparência e Controle Social. INESC, Brasília, 2005.

Almeida, Mansueto; Giambiagi, Fabio; PessoA, Samuel. Expansão e dilemas no controle do gasto público federal. Boletim de Conjuntura, n. 73, 2006.

Azeredo, Beatriz; Ramos, Carlos Alberto. Políticas públicas de emprego: experiências e desafios. Planejamento e Políticas Públicas, n.12, 1995.

Barros, Ricardo P.; Corseiul, Carlos Henrique; Foguel, Miguel. Os incentivos adversos e a focalização dos programas de proteção ao trabalhador no Brasil. Brasília: IPEA, 2001. (Texto para Discussão, 784)

Borges, M. Uma contribuição ao debate do Sistema Nacional de Emprego. Revista da ABET, Ano 3, n.5, 2003.

Bresser-Pereira, Luiz C. Economia política do gasto social no Brasil desde 1980/85. Econômica, Rio de Janeiro, n.1, v. 5, jun.2003.

Brasil/MF. Gasto social do governo central - 2001-2002. Brasília: Secretaria de Política Econômica/Ministério da Fazenda, 2003.

Brasil/MF. Gasto social do governo federal - 2001-2004. Brasília: Secretaria de Política Econômica/Ministério da Fazenda, 2005.

Brasil/MTE. Planfor 1995/2002 - Oito anos de qualificação do trabalhador. Brasília: tem, 2002.

BRASIL/MTE. Bolsa de qualificação profissional - avaliação e perspectivas. Brasília: Ministério do Trabalho e Emprego, 2002.

BRASIL/MTE. Construção de um sistema público de emprego, trabalho e renda integrado e participativo. Guarulhos: MTE, 2005. (Texto consolidado com resoluções do II Congresso Nacional) EUROPEAN Union Council Decision of 12 July 2005 on Guidelines for the employment policies of the Member States. Official Journal of the European Union, 6.8.2005. GARCIA, Ronaldo Coutinho. Subsídios para organiz̧ar avaliações da ação governamental. Brasília: IPEA, 2001. (Texto para Discussão, 776)

Giambiagi, Fabio. A política fiscal do governo Lula em perspectiva histórica: qual é o limite para o aumento do gasto público? Brasília: IPEA, 2006. (Texto para Discussão, 1169) 
Harasty, Claire (Ed.). Successful employment and labour market policies in Europe and Asia and The Pacific. ILO. Employment Strategy Papers 4/2004.

Inter-American Development BAnK - IADB. Country program evaluation - Brazil (19932003). Office of Evaluation and Oversight. IADB, 2004.

Neves, Leonardo. Aumento de parcelas do seguro-desemprego ou politica ativa de mercado de trabalho? Brasília: MTE, 2003. Disponível em: <http://www.mte.gov.br/ EstudiososPesquisadores/ observatorio/Publicacoes/EstudosePesquisas/Conteudo/PoliticaAtivaouMaisSD.pdf>. Passos, Alessandro F.; Neves, Leonardo; Paiva, Luis H.. A focalização das políticas de emprego e renda. Teoria \& Sociedade n.9, 2002.

Ramos, Carlos Alberto. Las politicas de empleo em Brasil. OIT-Argentina, 2003.

São Paulo (Município). Desigualdade de renda e gastos sociais no Brasil: algumas evidências sobre o debate. São Paulo: Secretaria de Desenvolvimento, Trabalho e Solidariedade, 2003.

Schwarzer, Helmut; PaIva, Luis Henrique. Participação de beneficiários e não beneficiários da Previdência Social no mercado de trabalho. Informe de Previdência Social, n.11, v. 15, nov. 2003.

The World Bank. Brazil jobs report (Report n. 24408-BR). The World Bank, 2002. 


\section{Resumo - Resumen - Abstract}

A qualidade do gasto público e a avaliação das políticas sociais: o orçamento do Ministério do Trabalho no período 2000-2006

Luis Henrique Paiva

Nos últimos anos, o debate sobre a melhoria da qualidade do gasto público tem ganhado espaço crescente. As questões mais gerais do tema são relevantes, mas não substituem o exame específico dos gastos sociais dos diversos ministérios - razão pela qual a avaliação das políticas públicas é instrumento fundamental para melhoria do gasto. $O$ trabalho corrente faz uma avaliação da dinâmica orçamentária das políticas do Ministério do Trabalho e Emprego. Essa análise revela um crescente desequilíbrio: enquanto o valor destinado às políticas passivas de emprego aumentou brutalmente, os valores destinados às políticas ativas de emprego caíram significativamente. Esse cenário - oposto ao que seria desejável - é ainda mais preocupante na medida em que as políticas passivas de emprego não beneficiam os mais pobres. Neste contexto, o trabalho avalia a possibilidade de que parte dos recursos reservados para políticas passivas seja dirigido às políticas ativas de emprego.

Palavras-chave: qualidade do gasto público, orçamento, políticas de emprego, abono salarial

La cualidad de la expensa publica y la evaluación de las políticas sociales: el presupuesto del Ministerio de Trabajo de Brasil en el periodo 2000-2006

Luis Henrique Paiva

En los últimos años, la atención a la cualidad de las expensas publicas ha crecido en Brasil. Las cuestiones mas generales de la materia son, sin duda, muy importantes, pero no dispensan el análisis específico de los gastos de los ministerios - lo que hace de los estudios de evaluación de las políticas públicas un instrumento necesario para la discusión de la cualidad del gasto. Este trabajo hace un análisis del presupuesto federal asignado al Ministerio de Trabajo y Empleo de Brasil en los últimos siete años. Ese presupuesto presenta un creciente desequilibrio: el monto destinado a las políticas pasivas de empleo ha aumentado fuertemente, mientras que aquél orientado a las políticas activas de empleo ha disminuido significativamente. Tal escenario - opuesto a lo deseable - es aún peor, ya que las políticas pasivas brasileñas no favorecen a los más pobres. Este trabajo evalúa la viabilidad de utilizarse parte de los recursos asignados a las políticas pasivas en la financiación de políticas activas de empleo.

Palabras-clave: cualidad de las expensas publicas, presupuesto federal, políticas de empleo, abono salarial

The quality of the public expenditure and the assessment of social policies: the budget of the Brazilian Ministry of Labor during 2000-2006

Luis Henrique Paiva

Over the last years, the interest in the quality of the public expenditures has increased in Brazil. Although general issues related to this subject are important, they do not replace an agency-specific analysis of the expenditure, confirming the fact that policy assessment is a crucial tool to improve the quality of the public expenditures. This paper presents an analysis of the budget of the Brazilian Ministry of Labor, revealing a growing unbalance: the amount of funds addressed to passive employment policies has strongly risen, while the amount addressed to active employment policies has significantly diminished. This scenario - which, at first glance, is not desirable - is even more 
concerning considering that the passive employment policies that have been implemented in Brazil do not reach the poorest. In this context, the article assesses the possibilities of directing part of the resources destined to finance passive policies to active employment policies.

Key words: quality of the public expenditures, budget, employment policies, workers' monthly allowance (abono salarial)

Luis Henrique Paiva

Sociólogo, mestre em Sociologia pela Unicamp e doutor em Sociologia e Política pela UFMG. Membro da carreira de Especialista em Políticas Públicas e Gestão Governamental, do Ministério do Planejamento, Orçamento e Gestão. Contato: <lhspaiva@superig.com.br> 